\title{
Article \\ Mapping Online Geographical Indication: Agri-Food Markets on E-Retail Shelves
}

\author{
Guilherme Silva Fracarolli 1,2 (D) \\ 1 SOCIUS-Research Centre in Economic and Organizational Sociology, ISEG-Lisbon School of Economics \\ and Management, University of Lisbon, 1249-078 Lisbon, Portugal; guilherme.fracarolli@phd.iseg.ulisboa.pt \\ 2 Rural Development Division, Federal Superintendence of Agriculture, Livestock and Food Supply of São \\ Paulo, Ministry of Agriculture, Livestock and Food Supply, São Paulo 01327-002, Brazil
}

Citation: Fracarolli, G.S. Mapping Online Geographical Indication:

Agri-Food Markets on E-Retail

Shelves. Agronomy 2021, 11, 2385.

https: / / doi.org/10.3390/

agronomy11122385

Academic Editors: Djamilia Skripnuk,

Gulnara Romashkina and

Magdalena Sobocińska

Received: 13 September 2021

Accepted: 22 November 2021

Published: 24 November 2021

Publisher's Note: MDPI stays neutral with regard to jurisdictional claims in published maps and institutional affiliations.

Copyright: (C) 2021 by the author. Licensee MDPI, Basel, Switzerland. This article is an open access article distributed under the terms and conditions of the Creative Commons Attribution (CC BY) license (https:// creativecommons.org/licenses/by/ $4.0 /)$.

\begin{abstract}
Economics has been trying to understand market functioning for a long time. However, the neoclassical approach does not satisfy the understanding of the mechanisms that operate in the construction, stabilization, and transformation of markets. For this reason, economic sociology proposes to provide subsidies from causal pluralism, rejecting explanatory theories of purely rational choices. Therefore, the use of sociological theories in the understanding of agri-food markets is also necessary. In this sense, this work aimed to compare the market for agri-food products with a geographical indication (GI) between the European Union (EU) and Mercosur, based on the performance of brands and supermarkets in both regions. For this, we used a data survey of thousands of products and respective GI registrations in the most prominent online markets of countries in both regions. We applied analyses that differentiated the economic blocs and used field theory to explain the phenomena found in the findings. The results indicated the formation of relevant bands in the GI market, a little voluminous, but capable of crossing borders, a second, with the majority of GIs found that are only commercialized locally, and a third invisible, where most products are located, which do not exist in these markets. Furthermore, supermarkets' own brands have great relevance and are decisive in building the market.
\end{abstract}

Keywords: geographical indication; field theory; market construction; e-retail; agri-food market; economic sociology

\section{Introduction}

Markets have been studied more deeply since the 18th century. The agri-food market is one of the firsts. To better understand the construction and the rules of the market, many economists, sociologists, and social scientists have worked on theories and observations of empirical facts. Say theorized the law of markets, which addressed the creation of demand through the production of goods and value creation as a defense of the laissez-faire idea for the capitalist economy [1]. Since then, the study of markets has taken new and different directions. Despite the relevant contributions on market functioning, the rules of exchange and the general parameters of supply and demand of neoclassical economics, this paper focuses on the economic sociology approach to bring new information and analysis on the market imperfections that break these rules.

Agri-food markets have different functioning mechanisms depending on the type of agricultural systems [2]. One niche of this market regards products with a specific geographical origin, qualities, or a reputation that are due to that origin. These products are protected by intellectual properties and are called Geographical Indication (GI) products [3]. These products are not only a differentiation tool for market purposes, but also a proposition to decommodify it [4,5]. Barham points to these products' natural, human, and historical factors as key to differentiation [6]. Allaire [7] (p. 63) refers to these factors as "the immaterialization of food and the institutionalization of quality," based on Goodman's work [8]. 
Although GI is a type of intellectual property (IP) protected worldwide by the Agreement on Trade-Related Aspects of Intellectual Property Rights (TRIPS), the rules of economic blocs and countries on its details and institutional mechanisms vary significantly [9]. Few studies have deepened the matter on the effects of these differences between the Mercosur and the (EU) [10], two major economic blocs with global economic impacts. Due to the presented gap regarding the arena and these two economic blocs, this work aimed to compare both regarding the brands in play in this niche market.

Although the most comprehensive agreement mentioned above took place in 1994, the development of protection systems and their respective markets took place in a globally heterogeneous manner. Therefore, the subject has gained scientific attention in recent years. However, it has been concentrated in Europe, where this market is more prominent. However, the reasons for this market to have developed in different ways, producing such different results still need to be understood. The formation of an economic bloc should facilitate economic relations among its members, and promote an alignment of ideas and goals for the development of its members. However, while the European Union has developed its own system for the recognition, protection, and promotion of these products, Mercosur, for example, does not have a unified system, depending on the isolated work of each of its members [9]. Despite this fact, this is only one explanation aspect to approach the differences between the markets. Another potential influence on the development of these markets is the performance of private firms. Therefore, this work aimed to investigate the difference in the relationships between brands found in supermarkets in countries of both blocs, Mercosur and EU, and the development of the market for agri-food products with GI through the variety of products and brands in the existing universe.

The resourcefulness of the European market in this market niche is notorious, even serving as a model for other countries. However, which reasons and factors explain the differentiated performance in the European market? The difference in the numbers demonstrates a more significant capacity concerning other blocs to materialize food culture. Nonetheless, does this expressive number of records also emerge in exchange arenas such as supermarkets? Moreover, do economic blocs influence the market for these products from a business point of view? The South American region in question has a great diversity of agri-food and cultural products. Therefore, studies that seek to understand the differences between the markets of different economic blocs beyond the normative ones are necessary.

Mercosur and the European Union are two economic blocs of global importance. Both were created with the purpose of promoting regional development policies for their members according to local characteristics and cultures through the improvement of extranational governance. The EU presents a unified system for the bloc, while Mercosur does not. Their divergent performances in the agri-food products market partly reflect this normative difference. However, it is not a sufficient explanatory condition. Therefore, the investigation between these two blocs needs greater attention from the point of view of other actors involved in this market. In the present work, this refers to the firms.

The influence of institutions on markets has been vastly documented [11-14], even on agri-food markets $[9,15,16]$. However, there is more to find out and deepen the understanding of its functioning. Many works approach this market regarding producers [17-20], development [21-23], or consumer issues [24-27]. Moreover, there is also a need to approach this market from the arena's perspective. Little work has been done on the matter, especially in a comparative perspective of economic blocs. For this reason, this work regards the arena of exchange on the market of GI agri-food products.

Therefore, the objective of this work was to compare the e-retail market of GI agri-food products between Mercosur and the EU regarding the brands. To answer this question, this work used institutional approaches from sociological tools such as economic sociology provided by theories of Fligstein [11,28-31], Fligstein and Dauter [32], and Allaire [15,16,33,34]. The institutional perspective has been growing on economic approaches. However, since the formation of the classical and neoclassical schools, several economic questions have remained unanswered due to the limits of their explanatory capacity. This gap allowed new 
authors to propose theories of a sociological nature through the lens of social construction to investigate markets. Since the formation of the classical and neoclassical schools, several economic questions have remained unanswered due to the limits of their explanatory capacity. Since then, authors such as North have proposed including institutions as a structuring part of economic and social development [13]. More recently, authors like Acemoğlu [14,35-37], Fligstein [11,28,29,32,38], and Powell and DiMaggio [39] have introduced new elements and enriched the debate about the involvement of institutions in the construction of markets.

To answer the present question, this work proposes to look at the brands on ecommerce of retailing supermarkets from both the EU and Mercosur's countries quantitatively. The supermarkets surveyed are from Portugal, Spain, France, Italy, Greece, Germany, and Poland on the EU side and Brazil, Argentina, Paraguay, and Uruguay on Mercosur's side. To analyze and properly compare both economic blocs, this work used an institutional perspective from the economic sociology approach to investigate the influence of brands on this market. The support will be provided from the collected data among the supermarkets from the countries mentioned above.

The present compared analysis hopes to collaborate to the market investigation of GI agri-food products and go further and reveal issues of market functioning. In addition, economic sociology will provide tools to understand the embeddedness of institutions and companies on GI agri-food towards market control.

Firstly, the work presents the major issues on the GI market, its origins, and production logic. Then, in the same section, it brings the state of the art of economic, sociological approaches, oriented by an institutional perspective, as well as the main theories, to sustain the future analysis. Finally, it ends the section by presenting the present situation of both economic blocs.

Then, the methodology is presented to build the parameters of data collection from e-retail supermarkets towards product characterization, brand specification, and visual tools in order to analyze and compare the GI markets on both blocs properly.

Afterward, we display the results expressed in the methodology section, containing the numbers found and graphical data. Then, we discuss the results according to the theoretical tools provided and their market implications, developing explanations to the differences and proposition to stakeholders. Finally, we summarize the findings and developments of the work and suggestions for future works, as well as commercial and public policies regarding geographical indication agri-food products.

The present study, by approaching the relationship of products and brands most present in online supermarkets in both regions, aims to contribute to the understanding of the operating mechanisms in this market niche. With this, elements are added to understand the behavior of private organizations in the construction of this market. Thus, this investigation presents new possible paths that still need to be further developed in specific fields in food sectors or other marketing channels.

\section{Agri-Food GI Market}

The globalization process pushed agri-food production towards massification and standardization of goods [2,40,41]. This process originates from the development of an intensification process of standardized products and the assembly line, defined as neoFordist [42-44]. This transformation of capitalist world logic is based on homogenous production and consumption from low complexity production systems. However, as a countermovement of such a process, initiatives towards attribution of quality and meaning seek cultural-related agri-food products [6]. GI products can answer this demand since localized agri-food systems bring valuable assets to this market $[45,46]$.

Nevertheless, it is well-known that GI products also function as a significant marketing tool [10-14] and pay bonus prices $[47,48]$. Furthermore, it is necessary to look at this market from the retailers' and sellers' perspectives. However, there still lacks researches on this matter in recent literature. Moreover, most of these works regard only single or few 
products $[18,22,49-52]$. Considering such a gap, this work focuses on studying GI products sold in retail supermarkets through e-commerce.

The agri-food sector addressed in this paper, despite being the result of historical constructions of products, has in e-retail a possible new path for marketing and expansion of the market. In the online field, there is still a lot to be studied and it shows up as ample room for advances. In this sense, studies show that the online marketing capacity of productive groups in their own channels still operates in a suboptimal capacity and is significantly heterogeneous [53,54]. On the other hand, the price paid for these products is higher [24,55-57]. However, the sales channels are still diffuse and there are few studies dedicated to the marketing of these products on online platforms.

The agrarian system developed in each region is significantly due to its formation. Such structure impacts the development of the GI niche. The significant difference can be seen in the numbers of registers on both blocs, which also reflects on academic work. Many of them focus on the European context due to its pioneers' system or the number of products. Nevertheless, few works approach the South American market and even less in a comparative manner, which justifies attention. The dimensional and populational differences between the European Union (EU) and the Southern Common Market (Mercosur) are abundantly clear. However, there is still much to investigate between the GI market differences between them. Despite the bloc difference, there are also differences intra-bloc $[9,50]$. Dias and Mendes, for example, show that most published papers regarding GI are about Mediterranean countries and are primarily empirical [50]. Thus, there is also a lack of a comparative approach to this niche market in different contexts and its effects and causes.

Since Adam Smith's [58] and Say's [1] works on economics and markets, much has been studied on market comprehension. Despite the numerous differences in assumptions and theoretical lines developed by researchers, the knowledge of economics has grown significantly. Early in history, the field of economics was dominated by an understanding that markets should be as free as possible with little or no interference by the state, sustained on liberal ideas. Such approach, developed over time, became dominant and is called classical, neoclassical, or even orthodox. However, other ideas gained life across the last century.

Nonetheless, at the beginning of the studies of economic phenomena, authors such as Weber, Durkheim, and Simmel used socially constructed methods to improve comprehension of such events. Thus, they founded the intersection between economics and sociology. These authors observed that institutions and other economic structures play some roles over economic issues. Furthermore, their work noticed that such phenomena are socially constructed through their relations with religion, social relations, state and other factors. However, the field of economic sociology remained dormant for years as an active academic area until recent events.

Despite the use of the term "embeddedness" firstly used by Polanyi [59], it was Granovetter who developed its characterization. For Polanyi, economy and social relations cannot be dissociated. However, there must be an appropriate discussion on the embeddedness of both in market economies, characterizing his substantivist argumentation [59]. In 1985, Granovetter wrote "Economic Action and Social Structure: The Problem of Embeddedness" [60], brought new life to the study of economic phenomena trying to fill the empty space left by orthodox economics. Among authors, Swedberg, White, Zelizer, MacKenzie, Beckert, and others led the analysis of economic matters towards new perspectives. This movement started to be called New Economic Sociology (NES). The NES "involves a body of study and research aimed at establishing the links between economic and social phenomena," as summarized by Trigilia [61] (p. 1).

Nevertheless, even the NES has its various approaches. The most common categorization of lines is that previously presented by Fligstein and Dauter [32] and Fourcade [62], three major theoretical paths to better comprehend the functioning of markets. These are networks [60,63-66], performativity [67-71] and institutions [11,28,38,39,72]. Due to the 
embedded relations of the state on the construction and regulation of the market regarding IP-protected products, the present work betakes the institutionalist via.

Institutional economics focuses on the relationship between customs, state, and norms, formal or informal, among people or groups as market makers. Despite the differences between authors regarding the most appropriate definition, they all assume that markets and the economy result from complex interactions between participating actors, conditioned by the specific circumstances of each one. Such an interpretation of the functioning and origins of economic phenomena places it as heterodox in this field by opposing to neoclassical economics approach.

The core of this theoretical line lay in learning, bounded rationality, and evolution. However, due to the theoretical progress of neoclassical economics, the NES also progressed and began to consider organizations, information, property rights, and transaction costs $[29,38,39]$ in the form of neo-institutionalism.

Since North developed an institutional theory toward economics by rejecting economic agents' pure rationality, much work has been done. The author first relied on the relevance of institutions on markets by defining constraint as a set of formal and informal rules in order to promote a stable environment on the market and society [13]. Then, he developed a theory on how institutions operate towards reducing asymmetry to reduce transactions costs [73]. His work brought new perspectives on market functioning due to multicausal factors and institutional relevance, despite his attachment to neoclassical thought.

After him, the NES was probably the field of research that has put major efforts into the involvement between institutions and the market. Authors such as Fligstein, Trigilia, and DiMaggio built theories on how these institutions affect markets. Block, for example, discussed the illusion of capitalist societies and economies by criticizing the common sense that markets are autonomous and self-regulated [74]. DiMaggio, on the other hand, focused more on organizations. In DiMaggio and Powell's work, the authors developed the argument related to the practices of organizations reaching for legitimacy in order to achieve trust and a tendency towards stability. Trigilia, on his side, built up a more conceptual formation of economic sociology and its sociological origins [61], although he also has worked on the analysis of local production systems development [75] and, additionally to this work, is his theory on "'embedded autonomy' of political action," in which the author argues on the relativity of social capital and the interaction between it political institutions [76].

Another theoretical approached that gained relevance in market analysis and explanation is the field theory. It gained life with Bordieu's work based on an agency-structure framework. The functioning of these structures obeys a hierarchical basis resulted from the struggle of social actors subordinated by power and class relations towards dominant positions $[77,78]$. Bourdieu built his theory on the habitus, understanding that the behavior of actors does not result from strictly rational decisions, but a set of their gut feelings and institutions [78,79].

At last, Fligstein developed the concept of field theory based on the understanding that "most social actions occur in social arenas where actors know one another and take one another into account in their action" [80] (p. 237). The author, along with McAdam, developed the theory on the premise that the world is made of constructed social orders in which incumbents and challengers compete to the dominance of the structure [81,82]. Fligstein argued on the existence of "meso-level" social orders. These orders are organized by individual and collective actors in hierarchical form and engage in disputes from towards dominance of a field. This struggle between incumbents and challengers leads to markets' creation, stabilization, and transformation [81].

Finally, Fligstein also developed the concept of social skill as a trigger to induce cooperation in the theory of fields. By focusing on the construction of local orders, the author rejects both rational choice and pure sociological versions [28]. Social skill, rooted in the symbolic interaction throughout the conceptions of Mead, Goffman, and Giddens, is based on the social process of assimilating the role of each actor according to their position 
in the field and how they behave in front of pre-existing rules. As a result, the behavior of the actors promotes its creation, stabilization, or transformation [28].

This paper develops under the neo-institutionalist frame to understand the difference of mechanics of Mercosur and the EU GI market. Or, in an adaptation of Fourcade, how do each embedded contexts of brands, supermarkets, and GI products operate to stabilize markets [62]? However, there is also a crucial component derived from the field theory. Nonetheless, the neo-institutionalist approach itself does not satisfy the full explanation of this aspect of the market. For that, field theory also will provide support.

\section{Methodology}

Considering that "markets are socially constructed arenas where repeated exchanges occur between buyers and sellers under a set of formal and informal rules governing relations among competitors, suppliers, and customers" Fligstein and Calder [83] (p. 1), the data collected must be analyzed under these circumstances. Therefore, the present work collected data on all GI products on the markets and the differences between both economic blocs. This work attempted to map the commerce of these products on retail supermarkets and hypermarkets through online shopping. To do such a survey on the market, on all supermarkets' websites, the address used to simulate was the city-center of the country's most populated city, if required. All GI agri-food products registered on the EU or Mercosur database were considered. Only agri-food products were collected and evaluated for this work; wines, spirits, and aromatized wines were not considered. The product categorization utilized was from the EU, as presented in Table 1.

Table 1. Product categorization.

\begin{tabular}{|c|c|}
\hline Category & Description \\
\hline 1.1 & Fresh meat \\
\hline 1.2 & Meat products \\
\hline 1.3 & Cheeses \\
\hline 1.4 & Other products of animal origin \\
\hline 1.5 & Oils and fats \\
\hline 1.6 & Fruits, vegetables and cereals fresh or processed \\
\hline 1.7 & Fresh fish, mollusks and crustaceans and derived \\
\hline 1.8 & Others such as spices \\
\hline 2.1 & Beers \\
\hline 2.2 & Chocolate and derived \\
\hline 2.3 & Bread, pastry, cakes and alike \\
\hline 2.4 & Beverages from plant extracts \\
\hline 2.5 & Pasta \\
\hline 2.6 & Salt \\
\hline 2.7 & Natural gums and resins \\
\hline 2.8 & Mustard paste \\
\hline 2.9 & Hay \\
\hline 2.10 & Essential oils \\
\hline 2.11 & Cork \\
\hline 2.12 & Cochineal \\
\hline 2.13 & Flowers and ornamental plants \\
\hline 2.14 & Cotton \\
\hline 2.15 & Wool \\
\hline 2.16 & Wicker \\
\hline 2.17 & Scutched flax \\
\hline 2.18 & Leather \\
\hline 2.19 & Fur \\
\hline 2.20 & Feather \\
\hline
\end{tabular}

Source: Author. Own elaboration based on categorization provided by the EU [84]. 
The first measure to be taken is to establish the parameters that allow the comparison performed in this work. The first and fundamental aspect is the comparison between economic blocs. Mercosur and the EU are institutions built and maintained by countries around the joint development of their member states, despite some differences in format. Both have agreements and rules regarding IP protection, and specifically in GI, with slight differences between the categories, as discussed by Fracarolli [9]. However, for comparison purposes, some considerations should be kept. While Mercosur has five member states, one of which is currently suspended, and the EU has 27 member states. Consequently, we need a comparative adaptation. Furthermore, the number of agri-food products with GIs registered in the two blocs is significantly different [9]. For these reasons, in order to ensure greater representation of both, it is reasonable to use a larger sample of EU countries to Mercosur. Therefore, it was possible to collect information from all active Mercosur members and a selection of seven countries was carefully picked from the EU, which account for more than $80 \%$ of the total number of registrations of GI products in the EU. Furthermore, for the results to become comparable, the figures must present numbers in relative terms and not in absolute terms so that there is no distortion.

Before searching the products sold in all countries, it was necessary to find the existing GIs. The universe of products and its classification and categorization used was the official listing of the EU and Mercosur's countries'. On the European side, this work examined the EU database at eAmbrosia [84]. Overseas, the considered data were from the available dataset from each authority from Argentina, Brazil, Paraguay, and Uruguay [85-87]. However, data from Paraguay and Uruguay still lack product registers, although Uruguay has GI wines. Since this work does not contemplate wines, spirits, or aromatized wines, there were no products from Uruguay or Paraguay. The work considered the types of GIs according to the respective laws of each economic bloc or country since Mercosur and the EU have different mechanisms of protecting these IP products, as observed by Fracarolli [9] and presented in Table 2 .

Table 2. Types of GIs.

\begin{tabular}{cc}
\hline Type & Description \\
\hline PDO & Protected Designation of Origin \\
PGI & Protected Geographical Indication \\
TSG & Traditional Specialities Guaranteed \\
DO & Denominação de Origem (Designation of Origin) \\
IP & Indicação de Procedência (Indication of Source) \\
IG & Indicación Geográfica (Geographical Indication) \\
\hline
\end{tabular}

Source: Author.

The research contemplates four major grocery retail supermarkets from each country with an active and functional website for online shopping for data collection. Therefore, this work went through four supermarkets in each country of Mercosur, totalizing 16 supermarkets. In the EU, the investigation went through four supermarkets' websites in seven countries, totalizing 28 supermarkets. The criterion for the seven countries from the EU was the most relevant ones on this market. Thus, in Mercosur, all active members were considered and from the EU, representing over $80 \%$ of its GI registers, ensuring relevant representation. Furthermore, all products with a GI label registered in the respective country were considered for each supermarket. The collection of data was realized between 2 January and 28 February of 2021.

After the established research parameters, we accessed the website of the 28 supermarkets as discussed and registered all agri-food products with GI belonging to any database mentioned among all the products made available on the e-commerce platform of these retails. 


\section{Results}

The results from the survey brought 289 different GIs on the EU's market and 25 different GIs on Mercosur's market, with 1784 and 388 different products, respectively. Additionally, the data in Supplementary Materials has information about the number of brands in each country.

The first notable aspect of the survey is the number of GI registers from within found face the number of existing GIs from within (Table 3). There is an underrepresentation of IP-protected products.

Table 3. GIs found versus existing GIs.

\begin{tabular}{cccc}
\hline Economic Bloc & GIs Found & Existing GIs & Percentage \\
\hline European Union & 286 & 1414 & $20.23 \%$ \\
Mercosur & 6 & 53 & $11.32 \%$ \\
\hline Source: Author & &
\end{tabular}

Source: Author.

Table 3 shows a significant difference in the number of existent registered GIs and the ones found on the survey. The commerce through e-retail in major supermarkets has shown that most GI products do not belong to this channel. Only a small, however significant, portion of these products is sold to final customers this way.

\subsection{European Union}

Fracarolli's work demonstrated the difference in the legal structure between the EU and Mercosur and the institutional effects on the markets of each region [9]. However, in addition to government involvement, there are also aspects that involve firms in this market.

Table 5 shows the number of brands that commercialize such products. It considers the brands by GI products, by category and the total amount. It is clear that only a few companies participate in this market through this way of commerce.

Table 4. The number of brands found in the EU.

\begin{tabular}{|c|c|c|c|c|c|c|c|}
\hline Country & GI Category & $\begin{array}{l}\text { Products Per } \\
\text { Category }\end{array}$ & $\begin{array}{c}\text { Total } \\
\text { Products }\end{array}$ & $\begin{array}{c}\text { Brands Per } \\
\text { Category }\end{array}$ & Total Brands & $\begin{array}{l}\text { Ratio Per } \\
\text { Category }\end{array}$ & Total Ratio \\
\hline \multirow{9}{*}{ France } & 1.1 & 6 & \multirow{9}{*}{462} & 3 & & 2 & \multirow{9}{*}{5.57} \\
\hline & 1.2 & 35 & & 15 & & 2.33 & \\
\hline & 1.3 & 267 & & 48 & & 5.56 & \\
\hline & 1.4 & 13 & & 5 & & 2.6 & \\
\hline & 1.5 & 19 & & 10 & 83 & 1.9 & \\
\hline & 1.6 & 77 & & 10 & & 7.7 & \\
\hline & 1.8 & 36 & & 14 & & 2.57 & \\
\hline & 2.5 & 4 & & 2 & & 2 & \\
\hline & 2.6 & 5 & & 3 & & 1.67 & \\
\hline \multirow{8}{*}{ Germany } & 1.2 & 46 & \multirow{8}{*}{174} & 12 & \multirow{8}{*}{43} & 3.83 & \multirow{8}{*}{4.05} \\
\hline & 1.3 & 103 & & 24 & & 4.29 & \\
\hline & 1.4 & 3 & & 1 & & 3 & \\
\hline & 1.5 & 5 & & 3 & & 1.67 & \\
\hline & 1.6 & 7 & & 5 & & 1.4 & \\
\hline & 1.8 & 4 & & 3 & & 1.33 & \\
\hline & 2.3 & 4 & & 3 & & 1.33 & \\
\hline & 2.5 & 2 & & 1 & & 2 & \\
\hline
\end{tabular}


Table 5. Cont.

\begin{tabular}{|c|c|c|c|c|c|c|c|}
\hline Country & GI Category & $\begin{array}{c}\text { Products Per } \\
\text { Category }\end{array}$ & $\begin{array}{c}\text { Total } \\
\text { Products }\end{array}$ & $\begin{array}{c}\text { Brands Per } \\
\text { Category }\end{array}$ & Total Brands & $\begin{array}{l}\text { Ratio Per } \\
\text { Category }\end{array}$ & Total Ratio \\
\hline \multirow{7}{*}{ Greece } & 1.2 & 3 & \multirow{7}{*}{283} & 2 & \multirow{7}{*}{87} & 1.5 & \multirow{7}{*}{3.25} \\
\hline & 1.3 & 235 & & 67 & & 3.51 & \\
\hline & 1.5 & 11 & & 6 & & 1.83 & \\
\hline & 1.6 & 26 & & 14 & & 1.86 & \\
\hline & 1.8 & 2 & & 0 & & $\mathrm{~N} / \mathrm{A}^{1}$ & \\
\hline & 2.3 & 4 & & 3 & & 1.33 & \\
\hline & 2.7 & 2 & & 0 & & $\mathrm{~N} / \mathrm{A}^{1}$ & \\
\hline \multirow{10}{*}{ Italy } & 1.1 & 1 & \multirow{10}{*}{330} & 0 & \multirow{10}{*}{65} & $\mathrm{~N} / \mathrm{A}^{1}$ & \multirow{10}{*}{5.08} \\
\hline & 1.2 & 67 & & 22 & & 3.05 & \\
\hline & 1.3 & 130 & & 18 & & 7.22 & \\
\hline & 1.4 & 1 & & 0 & & $\mathrm{~N} / \mathrm{A}^{1}$ & \\
\hline & 1.5 & 8 & & 6 & & 1.33 & \\
\hline & 1.6 & 31 & & 11 & & 2.82 & \\
\hline & 1.8 & 17 & & 9 & & 1.89 & \\
\hline & 2.1 & 2 & & 1 & & 2 & \\
\hline & 2.3 & 15 & & 8 & & 1.88 & \\
\hline & 2.5 & 58 & & 3 & & 19.33 & \\
\hline \multirow{6}{*}{ Poland } & 1.2 & 21 & \multirow{6}{*}{208} & 10 & \multirow{6}{*}{61} & 2.1 & \multirow{6}{*}{3.41} \\
\hline & 1.3 & 145 & & 39 & & 3.72 & \\
\hline & 1.5 & 10 & & 5 & & 2 & \\
\hline & 1.6 & 1 & & 1 & & 1 & \\
\hline & 1.7 & 11 & & 1 & & 11 & \\
\hline & 1.8 & 20 & & 8 & & 2.5 & \\
\hline \multirow{7}{*}{ Portugal } & 1.1 & 5 & \multirow{7}{*}{199} & 2 & \multirow{7}{*}{56} & 2.5 & \multirow{7}{*}{3.55} \\
\hline & 1.2 & 27 & & 14 & & 1.93 & \\
\hline & 1.3 & 94 & & 29 & & 3.24 & \\
\hline & 1.4 & 2 & & 2 & & 1 & \\
\hline & 1.5 & 38 & & 12 & & 3.17 & \\
\hline & 1.6 & 23 & & 3 & & 7.67 & \\
\hline & 1.8 & 10 & & 4 & & 2.5 & \\
\hline \multirow{7}{*}{ Spain } & 1.1 & 51 & \multirow{7}{*}{128} & 6 & & 8.5 & \multirow{7}{*}{4} \\
\hline & 1.2 & 16 & & 10 & & 1.6 & \\
\hline & 1.3 & 31 & & 16 & & 1.94 & \\
\hline & 1.5 & 1 & & 1 & 32 & 1 & \\
\hline & 1.6 & 18 & & 8 & & 2.25 & \\
\hline & 1.8 & 7 & & 3 & & 2.33 & \\
\hline & 2.3 & 4 & & 2 & & 2 & \\
\hline
\end{tabular}

${ }^{1}$ Not Available. Source: Author.

The presented table shows the number of products and brands found on the EU's e-retail markets survey. It shows that the number of products varies significantly between the bloc countries and the number of brands. The overall ratio among EU countries is between 3.25 and 5.57 products per brand. France and Italy are the most concentrated markets. On the other side, Greece and Poland are the least concentrated.

Additionally, the cheese category has the most products in all countries, except in Spain, where meat products prevail. On isolated categories, the most concentrated are the pasta in Italy, fresh fish, mollusks, and crustaceans and derived in Poland, and fresh meat in Spain. On the other hand, the less concentrated with more than one product are other animal products from Portugal and Italy, and other products such as spices and bread, pastry, cakes, and alike from Germany and Greece. Finally, only 13 categories out of 28 appeared on the survey. 
Another aspect of the market is the ratio of GI registers related to the number of brands found in the survey in each country. Figure 1 shows that most GIs do not appear in the market in many brands. Additionally, no country had more than $29 \%$ of GIs with four or more brands in its supermarkets in all surveyed countries. In this case, France was the one with the most relative variety of brands in GIs. On the other hand, Spain had $80 \%$ of the GIs found under only one brand or no brand.

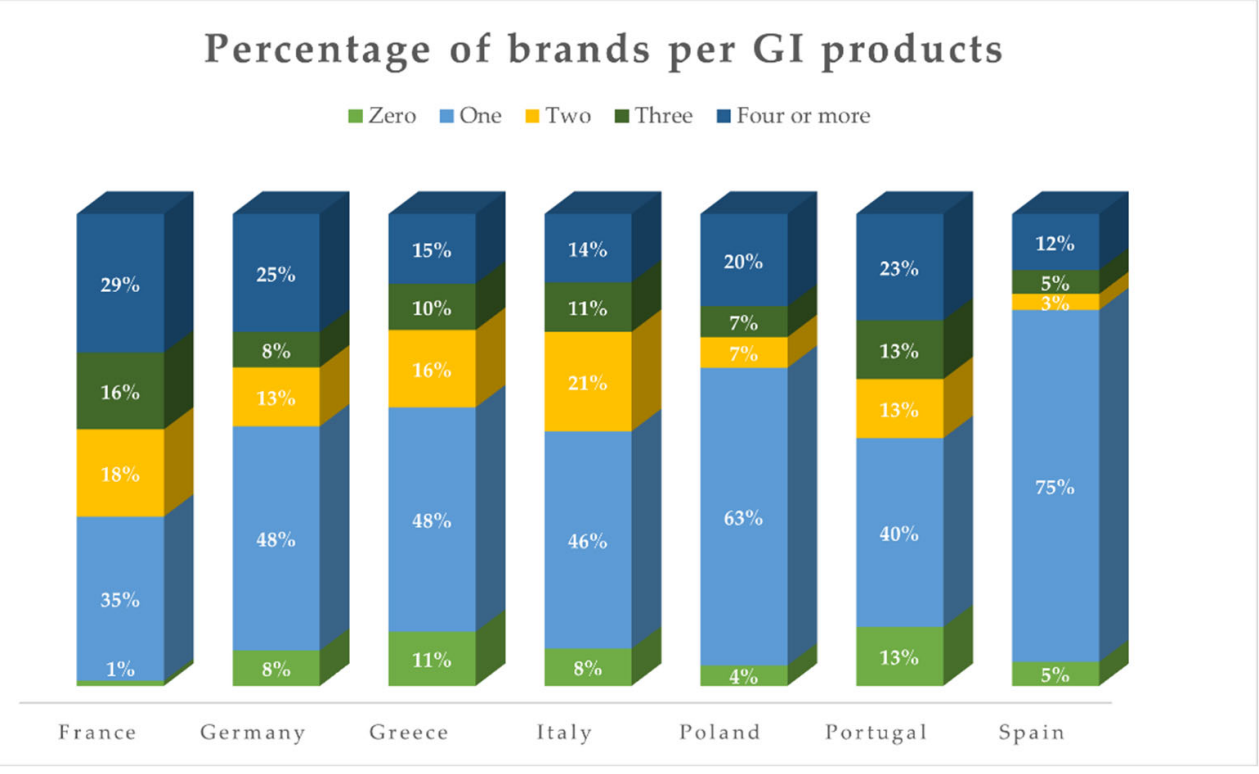

Figure 1. Percentage of brands per GI products in each country of EU. Own elaboration.

The data presented in Figure 1 demonstrate that most products with GI have very few players in all countries surveyed. The data presented in Figure 1 demonstrate that most products with GI have very few players in all countries surveyed. There are at least $36 \%$ of GIs with no or only one brand in all of them. France is the country with the lowest percentage. Likewise, it was also the country with the highest percentage of GIs with four or more brands on virtual shelves. The most prominent case is Spain, where $80 \%$ of the GIs found even have a brand. At the same time, it also proved to be the country with the lowest percentage of GIs represented by four or more brands.

Finally, in Figure 2, it is possible to observe the result of the research regarding the number of GIs where at least one of the supermarkets sampled has its own brand in the commercialization of agri-food products protected with this type of IP.

Figure 2 above shows the result, in each EU sampled country, of the corresponding percentage of GIs with at least one private label among the supermarkets observed. The results point to a massive presence of these brands in the market in question. The lower highlights are due to Poland and Greece, where $28 \%$ of GIs have at least one brand of their own in the markets observed. At the other end, France stands out, where $70 \%$ of the GIs found have their own brands in the supermarkets sampled. 


\section{Presence of supermarket's brand on GI products}

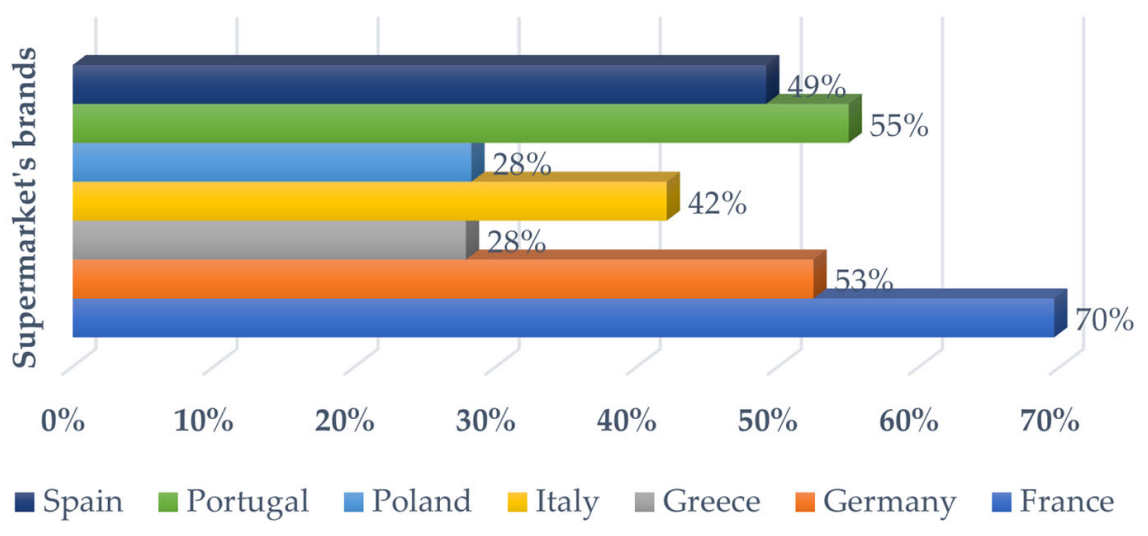

Figure 2. Presence of supermarket brands on GI agri-food products. Own elaboration.

\subsection{Mercosur}

Beyond formal institutional and governmental influence, markets operate under informal rules that may vary in each region. In the following subsection, we present the results found on the South American e-retail supermarkets survey according to previously specified.

Table 6 shows the number of brands that commercialize such products. It considers the brands by GI products, by category and the total amount. It is clear that only a few companies participate in this market through this way of commerce.

Table 6. The number of brands found on Mercosur.

\begin{tabular}{|c|c|c|c|c|c|c|c|}
\hline Country & GI Category & $\begin{array}{l}\text { Products per } \\
\text { Category }\end{array}$ & $\begin{array}{c}\text { Total } \\
\text { Products }\end{array}$ & $\begin{array}{c}\text { Brands per } \\
\text { Category }\end{array}$ & Total Brands & $\begin{array}{l}\text { Ratio per } \\
\text { Category }\end{array}$ & Total Ratio \\
\hline \multirow{3}{*}{ Argentina } & 1.2 & 22 & \multirow{3}{*}{180} & 5 & \multirow{3}{*}{37} & 4.4 & \multirow{3}{*}{4.86} \\
\hline & 1.3 & 10 & & 7 & & 1.43 & \\
\hline & 1.8 & 148 & & 25 & & 5.92 & \\
\hline \multirow{5}{*}{ Brazil } & 1.2 & 16 & \multirow{5}{*}{60} & 7 & \multirow{5}{*}{23} & 2.29 & \multirow{5}{*}{2.61} \\
\hline & 1.3 & 16 & & 7 & & 2.29 & \\
\hline & 1.5 & 5 & & 2 & & 2.5 & \\
\hline & 1.6 & 2 & & 0 & & $\mathrm{~N} / \mathrm{A}^{1}$ & \\
\hline & 1.8 & 21 & & 7 & & 3.0 & \\
\hline \multirow{3}{*}{ Paraguay } & 1.2 & 7 & \multirow{3}{*}{43} & 2 & \multirow{3}{*}{13} & 3.5 & \multirow{3}{*}{3.31} \\
\hline & 1.3 & 13 & & 6 & & 2.17 & \\
\hline & 1.8 & 23 & & 5 & & 4.6 & \\
\hline \multirow{3}{*}{ Uruguay } & 1.2 & 38 & \multirow{3}{*}{105} & 10 & \multirow{3}{*}{29} & 3.8 & \multirow{3}{*}{3.62} \\
\hline & 1.3 & 43 & & 12 & & 3.58 & \\
\hline & 1.8 & 24 & & 7 & & 3.43 & \\
\hline
\end{tabular}

${ }^{1}$ Not Available. Source: Author. Own elaboration.

The presented table shows the number of products and brands found on the survey on Mercosur's e-retail markets. It shows that the number of products varies significantly between the bloc countries and the number of brands. The overall ratio among Mercosur's countries is between 2.61 and 4.86 products per brand. Argentina is the most concentrated market of this niche. On the other side, Brazil is the least concentrated. 
Additionally, the 1.8 category (other such as spices) is the one with most products in all countries, except in Uruguay, where cheese prevails. On isolated categories, the most concentrated are the 1.8 category in Argentina, mainly due to mate. On the other hand, the cheese category is less concentrated with more than one product, also from Argentina. Finally, only five categories out of 28 appeared on the survey.

Another aspect of the market is the ratio of GI registers related to the number of brands found in the survey in each country. Figure 3 shows that most GIs do not appear in the market in many brands. Additionally, no Mercosur country had more than $18 \%$ of GIs with four or more brands in its supermarkets in all surveyed countries. In this case, Argentina was the one with the most relative variety of brands in GIs. On the other hand, Argentina also had $64 \%$ of the GIs found under only one brand or no brand at all, although very close to Brazil (62\%) and Paraguay (63\%). This fact demonstrates the relative uniformity of the bloc to brand concentration in Mercosur's market.

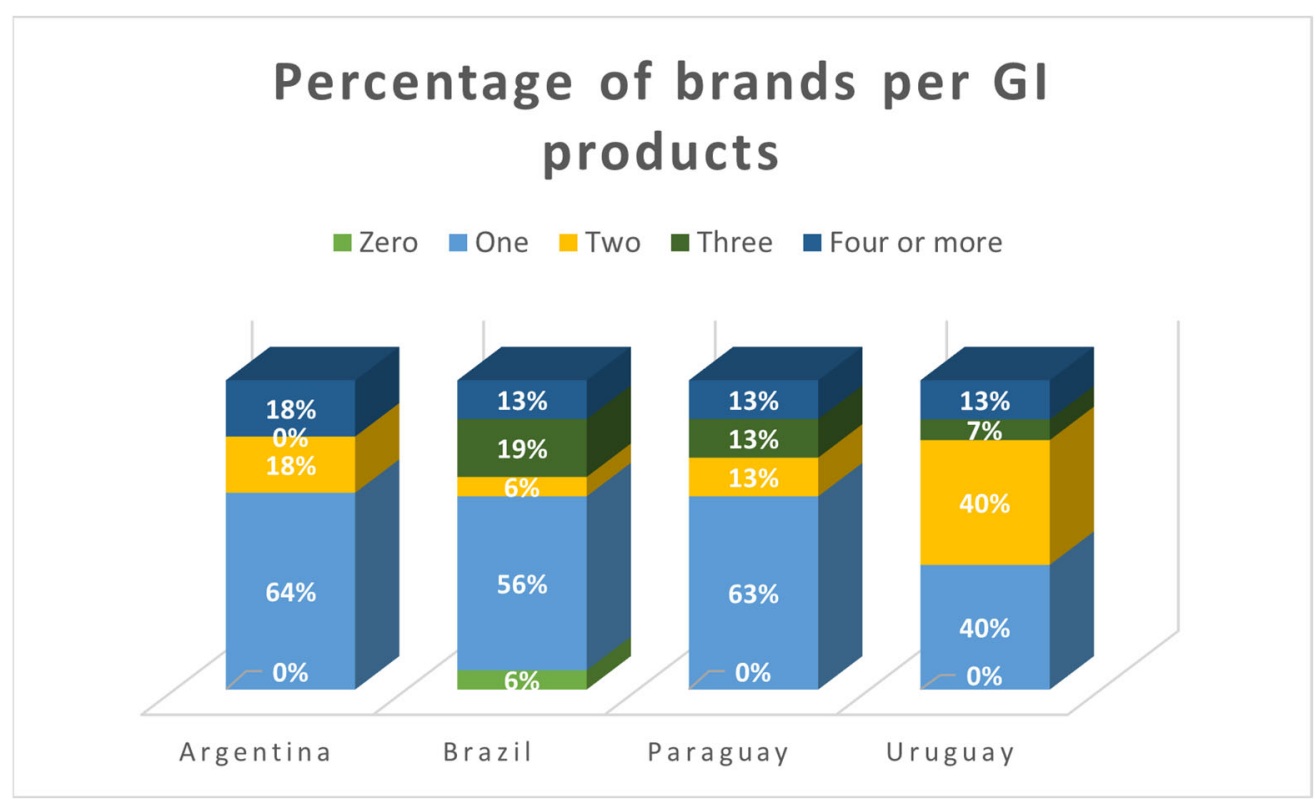

Figure 3. Percentage of brands per GI products in each country of Mercosur. Own elaboration.

The data presented in Figure 3 demonstrate that most products with GI have very few players in all countries surveyed. There are at least $40 \%$ of GIs with only one brand or none at all in all of them. Uruguay is the country with the lowest percentage. Likewise, Argentina had the highest percentage of GIs with four or more brands on virtual shelves $(18 \%)$. At the same time, Uruguay, Paraguay, and Brazil tied on the percentage of GIs represented by four or more brands.

Finally, in Figure 4, it is possible to observe the result of the research regarding the number of GIs where at least one of the supermarkets sampled has its own brand in the commercialization of agri-food products protected with this type of IP.

Figure 4 above shows the result of the corresponding percentage of GIs with at least one private label among the supermarkets observed in each Mercosur sampled country. Again, the results point to a rare presence of these brands in the market in question. The lower highlights are due to Uruguay and Paraguay, where no GIs have a brand of their own in the markets observed. At the other end, Argentina stands out, where $9 \%$ of the GIs found have their own brands in the supermarkets sampled. Again, however, the demonstrated sample opposes that found in the EU. 


\section{Presence of supermarket's brand on GI products}

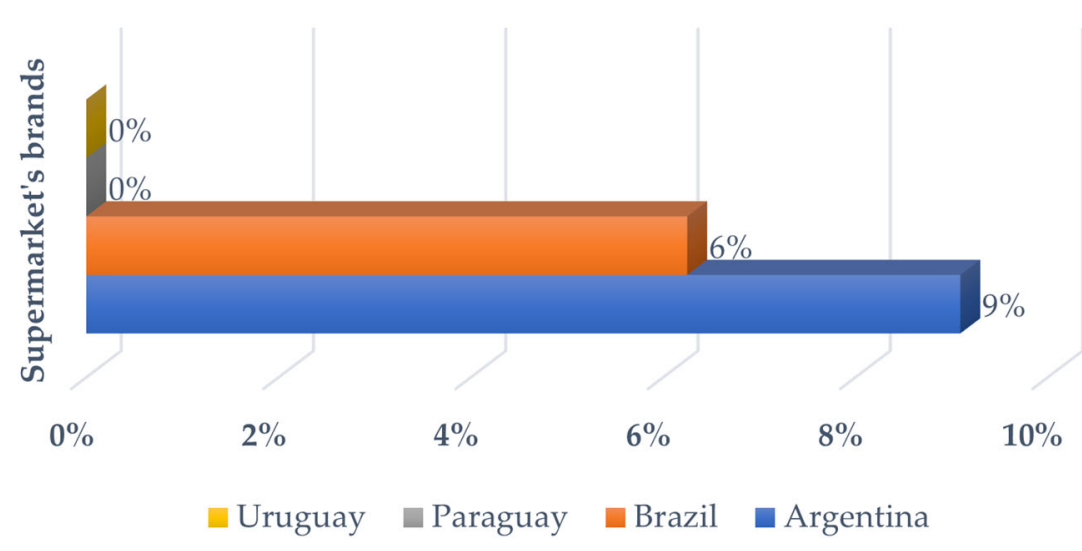

Figure 4. Presence of supermarket brands on GI agri-food products. Own elaboration.

\section{Discussion}

The following discussion is based on the results found from the samples performed as previously described. Since the sampling seeks to make the two blocs comparable, as they follow the same methodology, balanced by their proportionalities, the results express the existing reality and not sample weakness. Nevertheless, the glaring difference between the numbers found reinforces the need to understand the mechanisms that make the market for agri-food products with GI express such a difference.

The presented results bring new information about the market construction of GI agri-food products. The actors involved play a crucial role. The findings show that either in the EU or in Mercosur, the products found on the survey are from a restricted number of brands, which means that only major companies can penetrate the market. Each GI indeed has its major players, although the number of brands per category and the number per GI allow us to infer that these companies are even more restricted and commercialize more than one product within the same category.

These results are in line with research carried out that point to the difficulty of productive groups to insert themselves in online marketing channels [53,54]. Given the number of existing records, the potential of this market niche is clear, as well as the need to improve the flow and sale of goods.

Secondly, in both Mercosur and the EU, only a small percentage of the categories appear in the market [10]. Nevertheless, among the categories of products found, some of them stand out. For example, category 1.3 (cheese) is the category with the highest number of brands (and products) in all countries surveyed. Although the proportion of products by brand varies between countries, the relevance of this type of product in this market is significant. Even across countries, there are slight differences in the global proportion of products by brands. From the perspective of economic blocs, Mercosur is slightly less concentrated. However, there are also fewer brands and fewer products.

The study of brands in this market remains poorly studied. However, a significant part of studies related to GIs focus on certain products such as olive oil $[22,27,56,88]$ and wines $[18,52,89,90]$ in European markets and coffee $[4,49,51,91,92]$ in South American markets. Although wine is not part of this research, the others do not necessarily reflect the greater significance found in supermarket e-retail.

Thirdly, there is a clear difference in the number of products and the number of brands involved between Mercosur and the EU. The European market for agri-food products with GI has a more substantial presence in e-retail than in the South American market. There 
are a more significant number of companies involved in this market, although it is slightly more concentrated, due to the more significant number of products as well. In different ways, the role of the supermarkets' own brands in question is also relevant. The massive presence in European markets is notorious and almost non-existent in South American markets. Such presence denotes both the way supermarkets understand these products as strategic for the business and the effect caused by their entry, boosting and serving as a trigger for the products, like France, which has $70 \%$ of GIs with at least one private label product in the markets for sale. Even Poland and Greece, which had the lowest percentages in European terms, are three times more significant than Argentina. This Mercosur country had the most prominent presence of supermarkets' own brands.

The low number of studies that look at the South American market has been previously evidenced, mainly in studies that deal with the market in a broad spectrum and not directed to specific products. However, some studies point to the preference between brands and GIs among producers as a differential factor $[19,93,94]$, while this does not necessarily need to be an option, but their combination, aligned with the productive segment and political configuration, may have more promising effects.

The results extracted from this research allow us to infer that few brands dominate this market both in Mercosur and in the EU. Moreover, in this market, where those who trade and place themselves simultaneously as an exchange arena and as one of the points, that of the seller, these products stand out and are made dynamic. Additionally, agri-food products with GI are restricted to a few categories, and a few GIs are represented.

Nevertheless, the demonstrated endogeneity of the market still suggests that it is not just a matter of valuing local products, but of a potential market protectionism, as previously discussed [95-98], even though it needs to be further developed.

However, a few GIs manage to be marketed in countries outside their origin, but within the bloc. Even fewer products manage to be marketed outside the economic bloc. These players, despite being larger, constitute a very narrow product category, but with economic power and potentially influential in institutions. This group will be called the Upper Band. Thus, the actors in play closer or more embedded in the state have an advantage towards market control.

A significant part of the products sampled is only present in their countries of origin. The restriction, including intra-bloc, shows the low mobility and influence of local brands and supermarkets that sell these products. This fact configures the second level of products on the market that are restricted to local commerce, local brands, and have economic relevance. This group will be called the Intermediate Band.

Finally, a third and significant range of product categories are registered in their national and international systems, but do not appear in the markets, either because they no longer exist, or because they do not have brands capable of placing them in their respective marketing arenas, such as supermarkets in urban centers, or because they are only marketed locally, through local exchange systems. This group will be called the Lower Band. All these bands designated above make up a market conformation system as set out in Figure 5.

As previously mentioned, the institutions provide the structure in which this market is built. The construction of this market, especially in this arena, places different categories of players in the dispute. As shown in Figure 5, the three distinct groups characterized by agri-food products compete for space in the respective market-different GIs postulate market dominance as theorized by Fligstein and McAdam [82]. However, in the present market, there are invisible actors who must be appropriately considered.

It is clear that the dispute between incumbents and challengers is settled and visible. However, other actors may be present trying to participate in the market, but they are not. Thus, considering that all GIs are registered in their respective systems, regardless of the country or economic bloc in which they are located, there is a detachment of the agri-food products niche. Thus, it configures the formation of this market due to their differentiation, through IP protection through GI, to the respective products. 


\section{Brand Dominance on GI Markets}

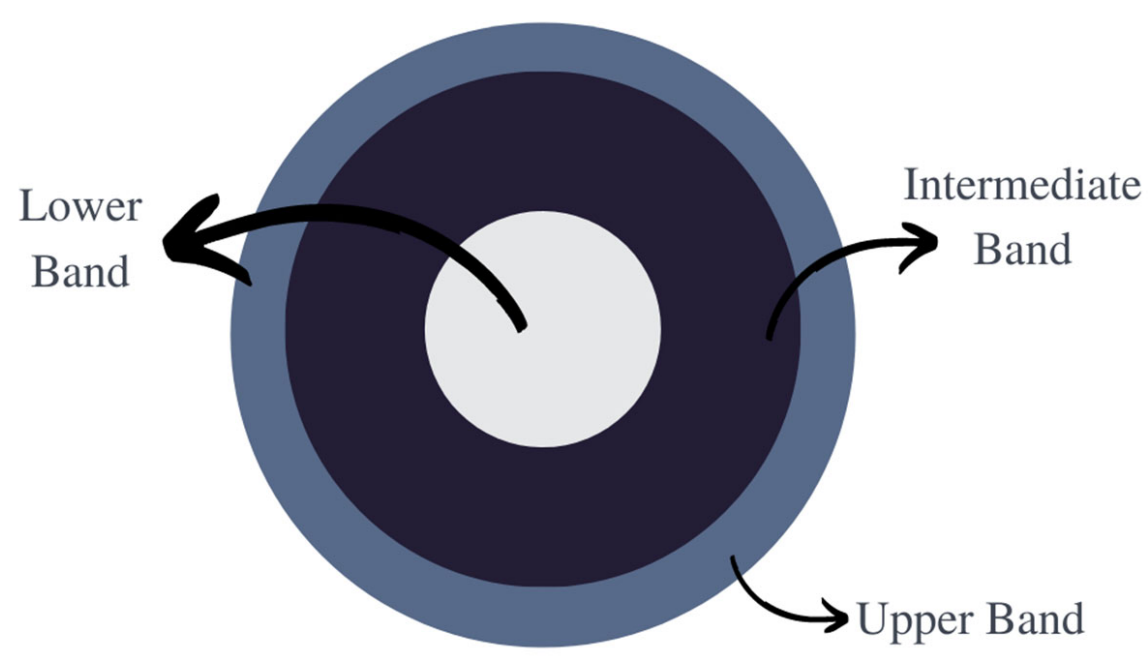

Figure 5. GI markets operating system for e-retail. Own elaboration.

Therefore, the protection afforded to the products and GIs found do justice to their existence and provide an existential nexus. These records provide the creation and participation of a different market. However, according to Fracarolli [10], around $80 \%$ of GIs in the EU and $90 \%$ in Mercosur are not present in e-retail supermarkets. In this sense, it is understandable that producers seek to protect the fruit of labor, history, and their environments [6]. A portion seeks registration as a form of protection for their intellectual property. Another portion sees registration as a marketing strategy, precisely to be able to participate in the market in question.

However, the significant portion of GIs that exist but are in a situation of invisibility raises the question of the very reason for their existence. These GIs neither protect these products nor serve as a marketing strategy, whether due to pressure from established GIs or inaccessibility to the market. In this sense, patrimonialization serves only as a productive or active whim for constructing regional identity but not as a market asset.

This same patrimonialization that materializes the local heritage is very useful to this product category [99]. However, the expenditure of time and public resources in the registration of these products in order to grow the market brings a reflection on the need to build coordinated and strategic actions regarding the formation of policies for the development of these products capable of sharing economic, environmental, labor factors and cultural.

The phenomenon observed here refers to the massive number of GIs that exist and are not present in the markets. We will call the Mirage Principle those who seek protective registration due to a possible entry into the market and are unable to do so. Analogously, we will call the phenomenon that affects those who seek protection for a product that does not have the threat of usurpation of the region's reputation for the product as the Hollow Principle. All of these constitute invisible actors who, in some way, are present in the market as a socially constructed environment, but who are not perceived either by brands or by the exchange arenas.

Then, as Bordieu first developed (however applied to different contexts), the field GI product market is also ruled by fields [77]. It is a power field displayed by a set of products granted to supermarkets and major brands that end up struggling towards market dominance. This competition, however, leaves the actual products and productive effort on a secondary relevance.

Fligstein highlights the formation of social fields as a theoretical organizational proposal for forming markets [28]. The proposal, as mentioned earlier, presents adequate and plausible explanations for this empirical study. Moreover, by situating the fields like 
construction and means of a dispute of firms, theory and practice come closer, as shown in Figure 5. Likewise, the cooperation between actors in order to obtain gains in the present market, as is typical of the producers of this nature of products, without which there would be no formation of terroir, as a result of the previously discussed symbolic interactionism, and finally, how actors use the structures proposed by the State to build the market in question.

Among the proposals made by Fligstein in the article "Social Skill and the Theory of Fields" [28], some of them could be verified and applied in the present empirical work. Proposal 3 (p. 117), for example, "Skilled social actors incumbent groups in stable fields will use existing rules and resources to reproduce their power," demonstrates how the Upper Band GIs use the established rules of protection regulation to exercise power and dominate the market and defend their status quo, as proposed in 6 (p. 118). Such proposals are echoed in the findings of this research. The Upper Band as the incumbents and the Intermediate Band as challengers for the present market. The commercial success of the GI minority in the Upper Band works as a social skill that motivates others to cooperate in the same direction.

In addition to providing a theoretical framework for the market in question, Fligstein's proposals allow for discoveries about the functioning of markets. As discussed, although firms use the structural framework built by the State for market development $[9,16,33]$, the massive presence of invisible actors shows the degree of imperfection in the institutional performance of rule makers, even in different systems. Thus, in addition to the construction of regulation being decisive in the formation of markets of this nature, it is equally necessary that institutions act in a coordinated manner in order to make them more functional and inclusive.

Finally, this article fulfills its objective of comparing the Mercosur and EU economic blocs regarding the role of brands in constructing the market for agri-food products with geographical indication. To this end, it uses the organizational theory proposed by economic sociology. The findings of this study contribute to the development of explanations of the functioning of markets as a social construction and reject simplistic explanations arising from the actors' rational choices. Supported by neo-institutionalism, we find gaps in the State's role in making it more functional, despite the differences between regions. In this sense, further studies can advance the explanation and inclusion of invisible actors in this market. Likewise, more studies on consumer behavior towards these products can add value to academia and society.

\section{Conclusions}

This study sought to investigate the role of brands in the market for agri-food products with GI in Mercosur and the EU through data collected in e-retail supermarkets. To this end, it collected information on the products offered and their GIs in four markets of each active Mercosur member and four markets of the seven most significant countries in terms of EU GI registrations.

To properly understand the functioning of markets from the perspective of brands, we sought to use the theoretical basis of organizations and economic sociology. In this sense, we understand that the Theory of Fields, rooted in the propositions of Bourdieu and Fligstein, provides a solid basis for understanding the market in question. The theory proposes forming fields of influence in which the actors involved in constructing markets compete or cooperate in occupying market positions. Thus, as they occupy certain positions, they tend to be copied and challenged.

The findings in this investigation reveal the formation of fields of influence of brands and GIs on the market. This formation takes place in an Upper Band, where GIs that are in markets beyond the country of origin and even in other economic blocs are consolidated products made up of significant brands or used by supermarket brands. There is an Intermediate Band, made up of local products and marketed only locally and the majority appears in the markets. Moreover, there is also a Lower Band in which GIs do not show up 
in the markets and are most records. The latter is formed by invisible actors who either no longer exist, cannot enter markets, or exist only in a localized sphere. In this case, the IP registration through GI does not make sense from a commercial point of view, neither to protect immaterial goods nor as a marketing strategy, incurring in what we call the Mirage Principle or Hollow Principle. Therefore, in the search for the same success, the actors reproduce the search for GI as a strategy of the dominant actors [100]. However, most end up incurring in the Mirage Principle.

The participation of supermarkets regarding the use of private labels in agri-food products with GI was also evaluated. The results show that the participation of private labels is significantly more intense in the EU. This factor makes the market in this niche more dynamic and plays a crucial role in placing and providing visibility to some GIs. For example, in France, 70\% of the GIs sold are also or only made by the markets' own brands. On the other hand, in Uruguay and Paraguay, supermarkets' own brands were not found in products with GI.

Likewise, although the State conceives the structure in which this market is constituted, some flaws are demonstrated by the number of invisible actors in it. By constituting the legal framework and IP parameters that differentiate and constitute a market niche, the State is an embedded part of this market, influencing and being influenced by the participating actors. Moreover, players use these structures to position themselves in the market and occupy positions of incumbents or challengers. Thus, we also add the invisible position. However, given the difference in results between the economic blocs, it is necessary to understand how the State acts on the formation, stabilization, and transformation of the market and the need for coordinated and strategic action in this regard. Even more research is needed to unveil triggers that can make this market more inclusive and functional.

However, despite advances in understanding the markets and the functioning of this niche, some issues still require advances. Significant contributions in expanding the coordinating and plural participation of organizations by the State proved to be necessary. However, there is still a need for further studies to delve into ways to do it. Likewise, some Mercosur and EU countries were addressed in this work. However, it is convenient that other countries and other economic blocs are also addressed.

As a continued battle to the first field, some other questions are left to be answered. The level of stabilization present in this market is, nonetheless, required further examination over time. Nevertheless, the understanding of these issues can be used both by academia, by the State, and by consumers, producers, and traders to boost trade. The use of evidence in market construction can have sustainable consequences and promote development.

Finally, the present work did not intend to broach specific products, but to provide an overview of the market for GI agri-food products and the differences between the EU and Mercosur regarding the most prominent sectors and the organizational influence. Therefore, its scope is limited in this scope, carried out in the period of collection of information and in the electronic means used.

Supplementary Materials: The following are available online at https: / www.mdpi.com/article / 10.3390/agronomy11122385/s1, Table S1. Data_v1.1, Table S2. Specifications table.

Funding: This research received no external funding.

Institutional Review Board Statement: Not applicable.

Informed Consent Statement: Not applicable.

Data Availability Statement: The data presented in this study are openly available in Mendeley Data at doi:10.17632/x3gm8dnhpt.1.

Acknowledgments: The author wishes to thank M.P.C. and D.S.L. from the Lisbon School of Economics and Management and SOCIUS colleagues for their research support and assistance. 
Conflicts of Interest: The views and opinions expressed in this article are those of the author, and do not necessarily reflect the official position of the Brazilian Ministry of Agriculture, Livestock, and Food Supply.

\section{References}

1. Say, J.-B. A Treatise on Political Economy; Routledge: Boca Raton, FL, USA, 2017; ISBN 978-1-351-31568-5.

2. Fracarolli, G.S. Global Markets, Local Issues: The Hegemonic Process of Agri-Food Construction to Present Challenges. Land 2021, 10, 1182. [CrossRef]

3. World Intellectual Property Organization Geographical Indications. Available online: https://www.wipo.int/geo_indications/ en/index.html (accessed on 29 June 2021).

4. Galtier, F.; Belletti, G.; Marescotti, A. Are Geographical Indications a Way to Decommodify the Coffee Market? In Proceedings of the European Association of Agricultural Economists, Ghent, Belgium, 26 August 2008; p. 15.

5. Hinrichs, C.C. Embeddedness and Local Food Systems: Notes on Two Types of Direct Agricultural Market. J. Rural. Stud. 2000, 16, 295-303. [CrossRef]

6. Barham, E. Translating terroir: The global challenge of French AOC labeling. J. Rural. Stud. 2003, 19, 127-138. [CrossRef]

7. Allaire, G. Quality in economics: A cognitive perspective. In Qualities of Food; Manchester University Press: Manchester, UK, 2018; ISBN 0-7190-6854-1.

8. Goodman, D. Rethinking Food Production-Consumption: Integrative Perspectives. Sociol. Rural. 2002, 42, 271-277. [CrossRef]

9. Fracarolli, G.S. The Effects of Institutional Measures: Geographical Indication in Mercosur and the EU. Sustainability 2021, 13, 3476. [CrossRef]

10. Fracarolli, G.S. Mapping Online Geographical Indication: Agrifood Products on E-Commerce Shelves of Mercosur and the European Union. Economies 2021, 9, 84. [CrossRef]

11. Fligstein, N. Markets as Politics: A Political-Cultural Approach to Market Institutions. Am. Sociol. Rev. 1996, 61, 656. [CrossRef]

12. Hodgson, G.M. Economics and Institutions: A Manifesto for a Modern Insitutional Economics; University of Pennsylvania Press: Philadelphia, PA, USA, 1988.

13. North, D.C. Institutions. J. Econ. Perspect. 1991, 5, 97-112. [CrossRef]

14. Acemoglu, D.; Johnson, S. Unbundling Institutions. J. Politi-Econ. 2005, 113, 949-995. [CrossRef]

15. Allaire, G. Economics of Conventions and the New Economic Sociology and Our Understanding of Food Quality and New Food Markets and Trade Institutions: What are Markets that Pure Economics Does Not Know? In Proceedings of the Plenary Session 5 The New Landscape and the Need for an Extension to the Agricultural Economics Toolkit, Beijing, China, 16 August 2009.

16. Allaire, G.; Wolf, S.A. Cognitive Representations and Institutional Hybridity in Agrofood Innovation. Sci. Technol. Hum. Values 2004, 29, 431-458. [CrossRef]

17. Teuber, R. Consumers and producers expectations towards geographical indications. Br. Food J. 2011, 113, 900-918. [CrossRef]

18. Agostino, M.; Trivieri, F. Geographical Indication and Wine Exports. An Empirical Investigation Considering the Major European Producers. Food Policy 2014, 46, 22-36. [CrossRef]

19. Dentoni, D.; Menozzi, D.; Capelli, M.G. Group heterogeneity and cooperation on the geographical indication regulation: The case of the "Prosciutto di Parma" Consortium. Food Policy 2012, 37, 207-216. [CrossRef]

20. de Mattos Fagundes, P.; Padilha, A.C.M.; Sluszz, T.; Padula, A.D. Geographical Indication as a Market Orientation Strategy: An Analysis of Producers of High-Quality Wines in Southern Brazil. J. Database Mark. Cust. Strategy Manag. 2012, 19, 163-178. [CrossRef]

21. Ilbery, B.; Kneafsey, M.; Söderlund, A.; Dimara, E. Quality, imagery and marketing: Producer perspectives on quality products and services in the lagging rural regions of the european union. Geogr. Ann. Ser. B Hum. Geogr. 2001, 83, 27-40. [CrossRef]

22. Roselli, L.; Giannoccaro, G.; Carlucci, D.; De Gennaro, B. EU Quality Labels in the Italian Olive Oil Market: How Much Overlap Is There between Geographical Indication and Organic Production? J. Food Prod. Mark. 2018, 24, 784-801. [CrossRef]

23. Barjolle, D.; Paus, M.; Perret, A.O. Impacts of Geographical Indications-Review of Methods and Empirical Evidences. In Proceedings of the International Association of Agricultural Economists Conference, Beijing, China, 16-22 August 2009.

24. Aprile, M.C.; Caputo, V.; Nayga Jr, R.M. Consumers' Valuation of Food Quality Labels: The Case of the European Geographic Indication and Organic Farming Labels. Int. J. Consum. Stud. 2012, 36, 158-165. [CrossRef]

25. Bonnet, C.; Simioni, M. Assessing Consumer Response to Protected Designation of Origin Labelling: A Mixed Multinomial Logit Approach. Eur. Rev. Agric. Econ. 2001, 28, 433-449. [CrossRef]

26. Loureiro, M.L.; McCluskey, J.J. Assessing Consumer Response to Protected Geographical Identification Labeling. Agribus. Int. J. 2000, 16, 309-320. [CrossRef]

27. Menapace, L.; Colson, G.; Grebitus, C.; Facendola, M. Consumers' preferences for geographical origin labels: Evidence from the Canadian olive oil market. Eur. Rev. Agric. Econ. 2011, 38, 193-212. [CrossRef]

28. Fligstein, N. Social Skill and the Theory of Fields. Sociol. Theory 2001, 19, 105-125. [CrossRef]

29. Fligstein, N. The Architecture of Markets: An Economic Sociology of Twenty-First-Century Capitalist Societies; Princeton University Press: Princeton, NJ, USA, 2002; ISBN 0-691-10254-6.

30. Fligstein, N. The Transformation of Corporate Control; Harvard University Press: Cambridge, MA, USA, 1993; ISBN 0-674-90359-5. 
31. Fligstein, N. Euroclash: The EU, European Identity, and the Future of Europe; Oxford University Press: Oxford, UK, 2008; ISBN 0-19-954256-2.

32. Fligstein, N.; Dauter, L. The Sociology of Markets. Annu. Rev. Sociol. 2007, 33, 105-128. [CrossRef]

33. Allaire, G. Applying Economic Sociology to Understand the Meaning of "Quality" in Food Markets. Agric. Econ. 2010, 41, 167-180. [CrossRef]

34. Dervillé, M.; Allaire, G. Change of competition regime and regional innovative capacities: Evidence from dairy restructuring in France. Food Policy 2014, 49, 347-360. [CrossRef]

35. Acemoğlu, D.; Robinson, J.A. Paths to inclusive political institutions. In Economic History of Warfare and State Formation. Studies in Economic History; Eloranta, J., Golson, E., Markevich, A., Wolf, N., Eds.; Springer: Singapore, 2016; pp. 3-50. ISBN 978-981-101605-9.

36. Acemoglu, D.; Johnson, S.; Robinson, J.A. The Colonial Origins of Comparative Development: An Empirical Investigation. Am. Econ. Rev. 2001, 91, 1369-1401. [CrossRef]

37. Acemoglu, D.; Johnson, S.; Robinson, J. The Rise of Europe: Atlantic Trade, Institutional Change, and Economic Growth. Am. Econ. Rev. 2005, 95, 546-579. [CrossRef]

38. Fligstein, N. Social Skill and Institutional Theory. Am. Behav. Sci. 1997, 40, 397-405. [CrossRef]

39. Powell, W.W.; DiMaggio, P.J. The New Institutionalism in Organizational Analysis; University of Chicago Press: Chicago, IL, USA, 2012; ISBN 978-0-226-18594-1.

40. Kenney, M.; Lobao, L.M.; Curry, J.; Goe, W.R. Midwestern Agriculture in US Fordism: From the New Deal to Economic Restructuring. Sociol. Rural. 1989, 29, 131-148. [CrossRef]

41. Bonanno, A.; Constance, D.H. Globalization, Fordism, and Post-Fordism in Agriculture and Food: A Critical Review of the Literature. Cult. Agric. 2001, 23, 1-18. [CrossRef]

42. Campbell, I. The Australian Trade Union Movement and Post-Fordism-Revised Paper Presented to the Political Economy Conference. J. Aust. Political Econ. 1990, 26, 1-26.

43. Gahan, P. Mathews and the New Production Concepts Debate-Reply to Mathews, John. New Production Systems: A Response to Critics and a Re Evaluation. J. Aust. Political Econ. 1993, 31, 74-88.

44. Wilson, B.; Ewer, P. 'New' Production Concepts: Implications for Union Strategy. Labour Ind. A J. Soc. Econ. Relat. Work 1996, 7 , 123-143. [CrossRef]

45. Fernández-Zarza, M.; Amaya-Corchuelo, S.; Belletti, G.; Aguilar-Criado, E. Trust and Food Quality in the Valorisation of Geographical Indication Initiatives. Sustainability 2021, 13, 3168. [CrossRef]

46. Barham, E.; Sylvander, B. Labels of Origin for Food: Local Development, Global Recognition; CABI: Wallingford, UK, 2011; ISBN 978-1-84593-352-4.

47. Deselnicu, O.C.; Costanigro, M.; Souza-Monteiro, D.M.; McFadden, D.T. A Meta-Analysis of Geographical Indication Food Valuation Studies: What Drives the Premium for Origin-Based Labels? J. Agric. Resour. Econ. 2013, 38, $204-219$.

48. Cei, L.; Defrancesco, E.; Stefani, G. From Geographical Indications to Rural Development: A Review of the Economic Effects of European Union Policy. Sustainability 2018, 10, 3745. [CrossRef]

49. Teuber, R. Geographical Indications of Origin as a Tool of Product Differentiation: The Case of Coffee. J. Int. Food Agribus. Mark. 2010, 22, 277-298. [CrossRef]

50. Dias, C.; Mendes, L. Protected Designation of Origin (PDO), Protected Geographical Indication (PGI) and Traditional Speciality Guaranteed (TSG): A bibiliometric analysis. Food Res. Int. 2018, 103, 492-508. [CrossRef]

51. Renard, M.-C. The Interstices of Globalization: The Example of Fair Coffee. Sociol. Rural. 1999, 39, 484-500. [CrossRef]

52. Addor, F.; Grazioli, A. Geographical Indications beyond Wines and Spirits: A Roadmap for a Better Protection for Geographical Indications in the WTO/TRIPS Agreement. J. World Intell. Prop. 2002, 5, 865. [CrossRef]

53. Jorge-Vázquez, J.; Chivite-Cebolla, M.P.; Salinas-Ramos, F. The Digitalization of the European Agri-Food Cooperative Sector. Determining Factors to Embrace Information and Communication Technologies. Agriculture 2021, 11, 514. [CrossRef]

54. Cristobal-Fransi, E.; Montegut-Salla, Y.; Ferrer-Rosell, B.; Daries, N. Rural cooperatives in the digital age: An analysis of the Internet presence and degree of maturity of agri-food cooperatives' e-commerce. J. Rural. Stud. 2019, 74, 55-66. [CrossRef]

55. Lin, C. An empirical study on decision factors affecting fresh e-commerce purchasing geographical indications agricultural products. Acta Agric. Scand. Sect. B-Plant Soil Sci. 2020, 71, 541-551. [CrossRef]

56. Carlucci, D.; De Gennaro, B.; Roselli, L.; Seccia, A. E-commerce retail of extra virgin olive oil: An hedonic analysis of Italian SMEs supply. Br. Food J. 2014, 116, 1600-1617. [CrossRef]

57. Chilla, T.; Fink, B.; Balling, R.; Reitmeier, S.; Schober, K. The EU Food Label ‘Protected Geographical Indication’: Economic Implications and Their Spatial Dimension. Sustainability 2020, 12, 5503. [CrossRef]

58. Smith, A. The Wealth of Nations; Modern Library: New York, NY, USA, 1994; ISBN 978-0679424734.

59. Polanyi, K. The Great Transformation: The Political and Economic Origins of Our Time, 2nd ed.; Beacon Press: Boston, MA, USA, 2001.

60. Granovetter, M. Economic Action and Social Structure: The Problem of Embeddedness. Am. J. Sociol. 1985, 91, 481-510. [CrossRef]

61. Trigilia, C. Economic Sociology: State, Market, and Society in Modern Capitalism; John Wiley \& Sons: Hoboken, NJ, USA, 2008; ISBN 978-0-470-69285-1.

62. Fourcade, M. Theories of Markets and Theories of Society. Am. Behav. Sci. 2007, 50, 1015-1034. [CrossRef]

63. Burt, R.S. Structural Holes; Harvard University Press: Cambridge, MA, USA, 2021. 
64. Granovetter, M. The Impact of Social Structure on Economic Outcomes. J. Econ. Perspect. 2005, 19, 33-50. [CrossRef]

65. White, H.C. Where Do Markets Come From? Am. J. Sociol. 1981, 87, 517-547. [CrossRef]

66. White, H.C. Markets from Networks: Socioeconomic Models of Production; Princeton University Press: Princeton, NJ, USA, 2018; ISBN 978-0-691-18762-4.

67. Beunza, D.; Stark, D. Tools of the Trade: The Socio-Technology of Arbitrage in a Wall Street Trading Room. Ind. Corp. Chang. 2004, 13, 369-400. [CrossRef]

68. Callon, M. Introduction: The Embeddedness of Economic Markets in Economics. Sociol. Rev. 1998, 46, 1-57. [CrossRef]

69. Callon, M. What does it mean to say that economics is performative? In Do Economists Make Markets? MacKenzie, D., Muniesa, F., Siu, L., Eds.; Princeton University Press: Princeton, NJ, USA, 2020.

70. MacKenzie, D.; Millo, Y. Constructing a Market, Performing Theory: The Historical Sociology of a Financial Derivatives Exchange. Am. J. Sociol. 2003, 109, 107-145. [CrossRef]

71. MacKenzie, D. An Engine, Not a Camera: How Financial Models Shape Markets; MIT Press: Cambridge, MA, USA, 2008; ISBN 978-0-262-25004-7.

72. Dobbin, F. Forging Industrial Policy: The United States, Britain, and France in the Railway Age; Cambridge University Press: Cambridge, UK, 1994; ISBN 978-0-521-62990-4.

73. North, D.C. Transaction Costs, Institutions, and Economic Performance; Occasional Papers International Center for Economic Growth; ICS Press: San Francisco, CA, USA, 1992; ISBN 978-1-55815-211-3.

74. Block, F.L. Capitalism: The Future of an Illusion; University of California Press: Los Angeles, CA, USA, 2018; ISBN 978-0-520-95907-1.

75. Crouch, C.; Gales, P.L.; Trigilia, C.; Voelzkow, H. Local Production Systems in Europe: Rise or Demise? Oxford University Press: Oxford, UK, 2001.

76. Trigilia, C. Social Capital and Local Development. Eur. J. Soc. Theory 2001, 4, 427-442. [CrossRef]

77. Bourdieu, P. Distinction: A Social Critique of the Judgement of Taste; Harvard University Press: Cambridge, MA, USA, 1987; ISBN 978-0-674-26227-0.

78. Bourdieu, P. Outline of a Theory of Practice; Reprint Edition; Cambridge University Press: Cambridge, MA, USA, 1977; ISBN 978-0-521-29164-4.

79. Bourdieu, P. Pascalian Meditations; Stanford University Press: Stanford, CA, USA, 2000; ISBN 978-0-8047-3332-8.

80. Fligstein, N. The Theory of Fields and Its Application to Corporate Governance. Seattle UL Rev. 2015, 39, 237.

81. Fligstein, N.; McAdam, D. The Field of Theory. Contemp. Sociol. 2014, 43, 315-318. [CrossRef]

82. Fligstein, N.; McAdam, D. A Theory of Fields; Oxford University Press: Oxford, UK, 2012; ISBN 0-19-985995-7.

83. Fligstein, N.; Calder, R. Architecture of Markets. In Emerging Trends in the Social and Behavioral Sciences; John Wiley \& Sons: Hoboken, NJ, USA, 2015; pp. 1-14. ISBN 978-1-118-90077-2.

84. European Commission EAmbrosia. Available online: https://ec.europa.eu/info/food-farming-fisheries/food-safety-andquality/certification/quality-labels/geographical-indications-register/ (accessed on 26 November 2020).

85. INPI Pedidos de Indicação Geográfica no Brasil. Available online: https://www.gov.br/inpi/pt-br/servicos/indicacoesgeograficas / pedidos-de-indicacao-geografica-no-brasil (accessed on 26 November 2020).

86. Prosur Proyecta Secreto Industrial. Available online: https://www.prosurproyecta.org/uruguay/categoria-explorador/secretoindustrial/ (accessed on 26 November 2020).

87. Ministerio de Agricultura, Ganadería y Pesca Dirección Nacional de Alimentos y Bebidas-Indicación Geográfica y Denominación de Origen. Available online: http://www.alimentosargentinos.gob.ar/HomeAlimentos/IGeo/productos_reconocidos.php (accessed on 9 September 2020).

88. Roselli, L.; Carlucci, D.; De Gennaro, B.C. What Is the Value of Extrinsic Olive Oil Cues in Emerging Markets? Empirical Evidence from the U.S. E-Commerce Retail Market. Agribusiness 2016, 32, 329-342. [CrossRef]

89. Marlowe, B.; Lee, S. Conceptualizing Terroir Wine Tourism. Tour. Rev. Int. 2018, 22, 143-151. [CrossRef]

90. Skuras, D.; Vakrou, A. Consumers' Willingness to Pay for Origin Labelled Wine: A Greek Case Study. Br. Food J. 2002, 104, 898-912. [CrossRef]

91. Barjolle, D.; Quiñones-Ruiz, X.F.; Bagal, M.; Comoé, H. The Role of the State for Geographical Indications of Coffee: Case Studies from Colombia and Kenya. World Dev. 2017, 98, 105-119. [CrossRef]

92. Quiñones-Ruiz, X.F.; Penker, M.; Belletti, G.; Marescotti, A.; Scaramuzzi, S. Why Early Collective Action Pays off: Evidence from Setting Protected Geographical Indications. Renew. Agric. Food Syst. 2017, 32, 179-192. [CrossRef]

93. Boatto, V.; Defrancesco, E.; Trestini, S. The Price Premium for Wine Quality Signals: Does Retailers' Information Provision Matter? Br. Food J. 2011, 113, 669-679. [CrossRef]

94. Yue, C.; Marette, S.; Beghin, J.C. 3 How to Promote Quality Perception: Brand Advertising or Geographical Indication? Frontiers of Economics and Globalization. In Nontariff Measures with Market Imperfections: Trade and Welfare Implications; Emerald Group Publishing: Bingley, UK, 2013; Volume 12, pp. 73-98. ISBN 9781781907542.

95. Josling, T. The War on Terroir: Geographical Indications as a Transatlantic Trade Conflict. J. Agric. Econ. 2006, 57, 337-363. [CrossRef]

96. Swinnen, J.F. Economics and Politics of Food Standards, Trade, and Development. Agric. Econ. 2016, 47, 7-19. [CrossRef]

97. Huysmans, M.; Swinnen, J. No Terroir in the Cold? A Note on the Geography of Geographical Indications. J. Agric. Econ. 2019, 70, 550-559. [CrossRef] 
98. Meloni, G.; Swinnen, J. Trade and Terroir. The Political Economy of the World's First Geographical Indications. Food Policy 2018, 81, 1-20. [CrossRef]

99. Gade, D.W. Tradition, Territory, and Terroir in French Viniculture: Cassis, France, and Appellation Contrôlée. Ann. Assoc. Am. Geogr. 2004, 94, 848-867. [CrossRef]

100. Giddens, A. The Constitution of Society: Outline of the Theory of Structuration; University of California Press: Berkeley, CA, USA, 1984; ISBN 978-0-520-05292-5. 